\title{
Adhesion Molecules in Non-melanoma Skin Cancers: A Comprehensive Review
}

\author{
JOANNA POGORZELSKA-DYRBUS ${ }^{1}$ and JACEK C. SZEPIETOWSKI ${ }^{2}$ \\ 1 "Estevita” Specialist Medical Practice, Tychy, Poland; \\ ${ }^{2}$ Department of Dermatology, Venereology and Allergology, Wroclaw Medical University, Wroclaw, Poland
}

\begin{abstract}
Basal cell carcinoma (BCC) and squamous cell carcinoma (SCC) are the most frequently diagnosed cancers, generating significant medical and financial problems. Cutaneous carcinogenesis is a very complex process characterized by genetic and molecular alterations, and mediated by various proteins and pathways. Cell adhesion molecules (CAMs) are transmembrane proteins responsible for cell-to-cell and cell-to-extracellular matrix adhesion, engaged in all steps of tumor progression. Based on their structures they are divided into five major groups: cadherins, integrins, selectins, immunoglobulins and the CD44 family. Cadherins, integrins and CD44 are the most studied in the context of non-melanoma skin cancers. The differences in expression of adhesion molecules may be related to the invasiveness of these tumors, through the loss of tissue integrity, neovascularization and alterations in intercellular signaling processes. In this article, each group of CAMs is briefly described and the present knowledge on their role in the development of non-melanoma skin cancers is summarized.
\end{abstract}

Non-melanoma skin cancers (NMSC) are the most frequently diagnosed malignancies and their prevalence has increased dramatically over the last 30 years. Basal cell carcinoma (BCC) and squamous cell carcinoma (SCC) represent $99 \%$ of all NMSC. BCC, which constitutes $70 \%$

This article is freely accessible online.

Correspondence to: Prof. Jacek C. Szepietowski (ORCID: 0000-00030766-6342), Department of Dermatology, Venereology and Allergology, Wroclaw Medical University, Chalubinskiego 1 50-368 Wroclaw, Poland. Tel: +48 717842286, e-mail: jacek.szepietowski@umed.wroc.pl

Key Words: Cell adhesion molecules, non-melanoma skin cancer, basal cell carcinoma, squamous cell carcinoma, review. of NMSC develops from basal epithelial cells of hair follicles or pluripotent epidermal basal cells and has a metastatic rate of only $0.0028-0.05 \%$ (1). Depending on the different features of tumor cells, there are many histological types of BCC, with different, but still low metastatic potential (2). SCC develops from the proliferating squamous layer of the epidermis, shows a metastatic rate of $0,1-9,9 \%$ and contributes to approximately $75 \%$ of deaths due to $\operatorname{NMSC}(3,4)$. Although both skin cancers generally have a good prognosis, due to their high prevalence, they generate significant medical and financial problems worldwide. The most important risk factor of NMSC is exposure to the ultraviolet radiation, and both ultraviolet (UV) B and UVA play crucial roles in skin carcinogenesis affecting every stage, including direct cellular damage, production of reactive oxygen species, DNA alterations, and impairment of cell-mediated immune response (5).

A wide variety of risk factors of NMSC is known, such as Fitzpatrick I and II skin phototypes, age over 50 years, family history of skin cancers, chronic immunosuppression, long-lasting ulceration, and scars. In addition, exposure to carcinogenic substances, like arsenic and tobacco, HPV viruses, actinic keratosis, and chronic dermatoses, including lichen sclerosus, lupus erythematosus, and lichen planus, are associated with a higher risk of SCC (6).

Carcinogenesis is a very complex process; it is mediated by various proteins and pathways and characterized by genetic and molecular alterations. Changes in the expression or function of cell adhesion molecules (CAM) are involved in all steps of the progression of the malignancy, starting from the detachment of tumor cells from the primary site, intravasation into the blood, extravasation into distant tissues and formation of the secondary lesions.

Hence, the aim of the present review was to summarize the present knowledge on the role of CAM in the development of non-melanoma skin cancers. 


\section{Cell Adhesion Molecules: Division, Functions, and Physiological Involvement}

Cell adhesion molecules are transmembrane proteins responsible for cell-to-cell and cell-to extracellular matrix adhesion (7) playing also a crucial role in intercellular signaling and the structure of the extracellular microenvironment. Moreover, they play important roles in physiologic processes like embryogenesis and organ growth, cell migration and differentiation, and wound healing, and are fundamental elements for the maintenance of tissue integrity. However, over 100 different CAM participate in a variety of pathological processes such as inflammation, tumor invasion and metastasis (7). Changes in the expression and function of CAMs have been recently extensively studied. Based on their structures they are divided into five major groups: cadherins, integrins, selectins, immunoglobulins and CD44 family (Table I).

\section{Cadherins}

Cadherins are transmembrane glycoproteins and the most studied group of adhesion molecules, divided into classic cadherins (including E-epithelial, N-neural, P-placental), which are the main mediators of calcium-dependent cell-cell adhesions, and nonclassic cadherins, including desmosomal cadherins and newly discovered protocadherins (8). These adhesion molecules play a pivotal role during embryogenesis and morphogenesis and also in the maintenance of adult tissue architecture (8). They are widely present in the normal epithelium and determine its integrity. Major cadherins in the skin include E-cadherin and the desmosomal cadherin desmoglein 1 (9).

E-cadherin mediates interactions between keratinocytes and also between keratinocytes and Langerhans cells, which are the main immune cells of the skin $(10,11)$. Classic cadherins are composed of five extracellular domains, a transmembrane segment and an intracellular domain. The most studied and first identified is E-cadherin, also known as cadherin-1 or epithelial cadherin, which is expressed in almost all epithelial tissues and is responsible for epithelial integrity and cell polarity (12). The cytoplasmic domain of E-cadherin interacts with groups of cytoplasmic regulatory proteins called catenins, which mediate binding of the complex to cytoskeletal actin filaments. The E-cadherincatenin complex plays a key role in cellular adhesion, regulates cadherin stability, and functions in cell signaling (13). In the normal skin, E-cadherin shows homogeneous membranous distribution in the whole epidermis, with the exception of the lower pole of basal keratinocytes, which are in contact with the basement membrane (10).

Loss of expression or impairment of the function of Ecadherin leads to loss of cell polarity and changes in tissue architecture. The epithelial cells may acquire a mesenchymal-like phenotype, detach from their neighboring cells and migrate, and in case of neoplasms form metastases. This process is called epithelial-mesenchymal transition (EMT) and the loss of E-cadherin and expression of $\mathrm{N}$ cadherin, often called the "cadherin switch", is considered as the most important indicator of this phenomenon (1). In this context, E-cadherin is also known as a metastasis suppressor protein $(14,15)$.

Several studies showed abnormal expression of E-cadherin in various skin carcinomas. In BCC, there is an overall tendency for lower expression of E-cadherin, when compared with normal skin, and low expression is more frequently observed in the more aggressive histological types of the tumor (16-19). The observed reduction of E-cadherin expression was more pronounced in the infiltrative and morpheaphorm BCCs, while the superficial and nodular types generally demonstrate less reduced expression of this molecule $(17,20)$. Moreover, with the higher invasiveness of the tumor, the membranous expression of E-cadherin is reduced and the cytoplasmic expression is increased (21). It is consistent with the current state of knowledge that high Ecadherin expression in the cell cytoplasm and low expression in the cell membrane may be associated with tumor aggressiveness. In support, it has been suggested that correct cell adhesion requires strong membranous activity of Ecadherin $(22,23)$.

In contrast, it is noteworthy that there are reports revealing no difference in the expression of E-cadherin in the BCC specimens, regardless of their histological type (24-26). A possible explanation of such discrepancy could be the different tissue fixation methods used (25).

The results of the studies in SCC are more consistent. In almost all analyzed SCC specimens, the expression of Ecadherin was reduced compared with normal epidermis (18, 23-24, 27-32) and this reduction was more pronounced in less differentiated and more invasive tumors $(29,33)$. However, the contribution of lower levels of E-cadherin in the metastatic process is still debatable, with conflicting results demonstrating either lower or a similar expression of this molecule in tumors with and without lymph node metastases $(24,25)$, although once more, the different fixation method utilized in one of those studies could explain such difference (25).

Many studies on E-cadherin showed its contribution in both SCC and BCC, but only a few investigations have been conducted on N-cadherin in NMSC. N-cadherin is not found in normal squamous epithelium, although is known for angiogenesis stimulation in some cancers (33). In BCC, Ncadherin was found to be up-regulated in the metastatic, but not in non-metastatic tumors (34), while in SCC, the tumors expressing $\mathrm{N}$-cadherin demonstrated higher invasiveness (35). The low number of publications concerning N-cadherin 
Table I. The major families of cell adhesion molecules involved in the pathogenesis of non-melanoma skin cancers.

\begin{tabular}{|c|c|c|}
\hline Family & Members with importance in the skin & $\begin{array}{l}\text { Involvement in pathogenesis of } \\
\text { non-melanoma skin cancers }\end{array}$ \\
\hline Cadherins (more than 100 different types) & $\begin{array}{c}\text { Classic: } \\
-\mathrm{E} \\
-\mathrm{N} \\
-\mathrm{P} \\
\text { Desmosomal: } \\
\text {-Desmocollins } \\
\text {-Desmogleins } \\
\text { Unconventional: } \\
-\mathrm{T}\end{array}$ & $\begin{array}{l}\text { Epithelial-mesenchymal transition } \\
\quad \text { Cell adhesiveness } \\
\text { Markers of epithelial differentiation }\end{array}$ \\
\hline $\begin{array}{l}\text { Integrins } \\
\text { Heterodimers of subunits } \alpha \text { and } \beta\end{array}$ & $\begin{array}{c}-\alpha 2 \beta 1 \text { (collagen receptor) } \\
-\alpha 3 \beta 1 \text { and } \alpha 6 \beta 4 \text { (laminin receptors) } \\
-\alpha 5 \beta 1 \text { (fibronectin receptor) }\end{array}$ & $\begin{array}{l}\text { Single cell migration } \\
\text { Metastases } \\
\text { Signaling }\end{array}$ \\
\hline $\begin{array}{l}\text { Selectins } \\
\text { Immunoglubulin family (IgSF) } \\
\text { CD44* }\end{array}$ & $\begin{array}{c}\text { E } \\
\text { ICAM, VCAM, PECAM, NCAM } \\
\text { Nectin family } \\
\text { CD44s, CD44v6-9 }\end{array}$ & $\begin{array}{c}\text { Metastases } \\
\text { Marker of neovascularization }\end{array}$ \\
\hline
\end{tabular}

*The CD44 family consists of the standard CD44s and at least $10 \mathrm{CD} 44 \mathrm{v}$ isoforms.

in NMSC might indicate that the EMT phenomenon in which cells lose epithelial and acquire mesenchymal markers needs further investigations in both SCC and BCC, as its mechanism might involve additional molecules, not yet assessed in these tumors.

Like other classic cadherins, P-cadherin is important for cell differentiation during embryonic development as well as for the maintenance of normal architecture of mature tissues (12). This molecule is present in the cells of the basal layer of the normal epidermis, therefore is considered as an indicator of proliferation, and is usually co-expressed with E-cadherin $(36,37)$. However, both BCC and especially the peripheral sites of non-metastatic SCC specimens, demonstrate P-cadherin expression similar to the normal skin, whereas lower expression is observed only in the metastatic SCCs $(36,38)$. Hence, it appears that it does not play a significant role in skin carcinogenesis.

Nonclassic cadherins - desmogleins (DSG) and desmocollins (DSC) - play the role in the formation of desmosomes, which are the structures connecting epithelial cells. Desmoglein 1 is localized mainly in the superficial upper layers, and desmoglein 2 and 3 in basal and suprabasal layers of the normal epidermis, respectively (39). Desmocollins and desmogleins are localized in the upper layer 2 and 3 in the lower layers of the epithelium, respectively (39).

Expression of DSG1 was found to be significantly reduced in all cases of SCC and in cases of nodular BCC, and completely absent in the morpheaphorm and superficial types of BCC (40). Similarly, the reduced expression of DSG3 has also been demonstrated in BCC specimens (39). In contrast, DSG2 is significantly more intensively expressed in both types of NMSC, and its higher expression occurs more frequently in poorly differentiated SCCs $(39,41)$. The discordant expression of these molecules might be related to the fact that DGS2 is regarded as a protein associated with proliferation and aggressiveness of tumor cells, and a marker of lower differentiation (42). As only insignificant differences in the expression of DSC 1-3 in the NMSC have been reported so far, their role in cutaneous carcinogenesis is still not unequivocal (43).

T-cadherin belongs to the nonclassical cadherins and in normal skin is expressed on keratinocytes of the basal cell layer of the epidermis. Although its function in the biology of the skin remains unclear, it has been considered as a suppressor of tumourigenesis in various cancers $(9,44)$. Although low expression of T-cadherin has been observed in both BCC and SCC (44-46), there is contradictory evidence of even higher expression in BCC specimens, regardless of the histological type (47). Therefore, the role of this adhesion molecule in the development of NMSC appears to be much more complicated and requires further investigations $(46,48)$.

\section{Integrins}

Integrins are heterodimeric transmembrane proteins composed of $\alpha$ and $\beta$ subunits. At present, $18 \alpha$ and $8 \beta$ subunits have been discovered, which in several combinations form 24 integrin complexes (49). These 
adhesion molecules consist of a larger extracellular domain, a single transmembrane domain, and a relatively small intracellular domain. The extracellular domain binds with connective tissue components such as collagen, fibronectin, laminin, whereas the intracellular domain of integrins interacts with the cytoskeleton. The integrins participate in cell-matrix and also in cell-cell adhesion and play an important role in various physiological processes including embryological development, hemostasis, wound healing, and signal transduction $(7,50)$.

The main integrins of normal human epidermis are $\alpha 2 \beta 1$ (collagen receptor), $\alpha 3 \beta 1$ and $\alpha 6 \beta 4$ (mainly laminin receptors). The $\alpha 5 \beta 1$ and $\alpha v \beta 6$ integrins (receptor for fibronectin) are expressed at nearly undetectable level in normal epidermis and their expression increases significantly during wound healing $(51,52)$. Integrins are known to be involved also in EMT. The "cadherin switch" discussed in the previous paragraphs of this article, is also characterized by changes in the expression of integrins from those containing $\beta 4$ subunits, present in hemidesmosomes, to those containing $\beta 1$ and $\beta 3$ subunits, which results in a higher cellular motility $(7,53,54)$.

Few studies on the expression of integrins in NMSC have been conducted. Studies on the expression of $\alpha 2 \beta 1$ and $\alpha 3$ $\beta 1$ integrins in BCC specimens have revealed high levels of these two adhesion molecules, with a tendency for a higher expression in nodular type compared to the morpheaform (52, 55-57). Moreover, localization of $\alpha 3 \beta$ 1integrins corresponded to areas with preserved basement membrane (52). Furthermore, epithelial cells of BCC expressed also $\alpha v, \alpha 4$ and $\alpha 5$, which were not present in the normal epidermis (58).

Staining of SCC for $\alpha 2 \beta 1$, and $\alpha 3 \beta 1$ subunits showed absence or low expression of these integrins, which could be related to higher malignancy of SCC compared with BCC (52).

\section{Selectins}

Selectins (Lec-CAM) are calcium-dependent transmembrane proteins composed of an $\mathrm{N}$-terminal lectin domain, an epidermal growth factor (EGF) domain, 2-9 protein repeats, a transmembrane domain and a small cytoplasmic domain (59). This class of adhesion molecules consists of endothelial $(\mathrm{E})$, leukocyte $(\mathrm{L})$ and platelet $(\mathrm{P})$.

E-selectin in normal skin demonstrates a weak expression in the microvessels and - so far - it seems to be the only selectin involved in cancer metastatic activity, probably through the interactions between endothelial cells and tumour surface selectin ligands $(50,60)$. The results of studies on the expression of E-selectin in the normal skin and NMSC revealed its negative expression in normal skin and positive expression in SCC and BCC. Moreover, in cases of $\mathrm{SCC}$, there was a strong positive staining for E-selectin on malignant keratinocytes and vascular endothelium. In contrast, no tumour cell staining, but endothelial expression of E-selectin was observed in BCC (61). Hence, future studies are warranted to examine the involvement of selectins in the biology of NMSC $(62,63)$.

\section{CD44}

The transmembrane cell surface molecule CD44, which is present multiple isoforms, is broadly distributed in a wide variety of tissues, including the skin, where it is distributed in the hair follicles, sweat glands and in the epidermis with the exception of the basement membrane and granular and corneous layers (64). The physiological distribution of CD44 is concordant with the distribution of hyaluronic acid as CD44 is thought to be a receptor for hyaluronic acid, and also an important ligand of E-selectin $(50,64,65)$.

The presence of CD44 in NMSC is controversial, although, in BCC, there is an overall tendency for lower expression (66-71). Some inconsistency in the results of the published studies remains regarding SCC. Although some of them demonstrated that the expression of CD44 in SCC is reduced, and decreased CD44 expression is mostly found in the more invasive and aggressive tumors $(65-66,69,72)$, other analyses did not confirm such findings $(68,71,73)$. However, in one of the contradictory studies, the process of specimen preservation was substantially different, as the samples were frozen and not paraffin-embedded, hence the availability of the antigens was significantly higher (74).

\section{The Immunoglobulin Family of Adhesion Molecules}

Immunoglobulin-like cell adhesion molecules constitute the largest and most diverse group of adhesion molecules, which includes vascular cell adhesion molecules (VCAMs), intercellular adhesion molecules (ICAMs), neural cell adhesion molecule (NCAMs), platelet endothelial cell adhesion molecule (PECAM), and nectins (7, 49). All members of this family consist of an extracellular domain (which contains one or more immunoglobulin-like domains), a single transmembrane domain, and a cytoplasmic tail (75). The VCAM (CD106) is widely distributed and highly expressed primarily in the endothelial cells (76). Its expression increases, especially in states of inflammation, on tissue macrophages, dendritic cells and epithelial cells (76, 77). Moreover, it plays the role of an endothelial ligand for VLA-4 (Very Late Antigen-4 or integrin $\alpha 4 \beta 1$ ) of the $\beta 1$ subfamily of integrins (78). A study on the expression of VCAM in SCC demonstrated its intense presence in poorly differentiated SCC, but only moderate expression in welldifferentiated SCC (79). VCAM-1 was not detected in BCC tissues and negative or weak staining was observed in the epidermis adjacent to $\operatorname{BCC}(61,80)$. The few publications concerning VCAM in NMSC might indicate that this 
molecule does not play any significant role in skin cancer development, although its increased expression in SCC tumors could potentially support the role of inflammation in the pathogenesis of these neoplasms.

The ICAM family consists of five members (ICAM-1 to ICAM-5), which are important elements of intercellular, but not cell-matrix adhesion (81). ICAM-1 (CD54) contains five Ig-like domains and is only occasionally detectable on keratinocytes of the normal skin, mostly in the T-cell-present regions. It is, however, found on endothelial cells, since ICAM-1 is one of the most expressed endothelial surface adhesion molecules (78). The primary role of ICAM-1 in the human skin is adhesion to the LFA-1, present on circulatory leukocytes. Studies on ICAM expression on NMSC revealed lack of expression on BCC tumour cells $(61,80,82-84)$ with minimal expression in the peritumoral stroma $(80,82,84)$. In SCC, a dramatic increase in ICAMs in poorly differentiated SCC was shown, while in well-differentiated tumors, there was only focal ICAM expression (79). These results are consistent with the pathophysiology of NMSC, as ICAM-1 expression on keratinocytes increases in chronic inflammatory conditions, which contributes to the development of SCC, but not BCC (81).

NCAM (CD56), another member of the immunoglobulin family, has originally been found on neuronal cells. It plays an important role in morphogenesis, in neural development and mediates intercellular adhesion in various tissues (85). Studies on this adhesion molecule in BCC and SCC revealed strong immunoreactivity in the majority of stained $\mathrm{BCC}$ specimens regardless of their histological type, and negative expression in almost all SCC samples (86-89). These results could indicate the difference in the origin of these NMSCs. As the cells of the hair follicle in the normal skin also demonstrate positive immunoreactivity for NCAM, its strong expression in BCC could be a consequence of its development from these cells, which has been supported by studies in recent preclinical models $(86,90-91)$. However, other theories regarding the origin of BCC should also be taken into consideration $(92,93)$.

PECAM (CD31) is physiologically involved in leukocyte migration, signal transduction and angiogenesis $(94,95)$. Staining of NMSC for CD31 showed its elevated expression in the areas adjacent to both SCC and BCC, when compared with normal skin, with expression significantly higher in the areas surrounding SCC $(80,96)$. In the tumor area, CD31 was identified in SCC, but not in BCC (96). However, in another study, the expression of CD31 did not differ significantly between SCC and BCC cases, and no difference was observed when consecutive different grades of SCC progression or the presence of tumor metastases were analyzed $(97,98)$. Hence, it appears that the difference in the metastatic potential of squamous and basal cell carcinomas is not only due to differences in angiogenesis, but also in multiple other factors.
Nectin family comprises four members and regulates various cellular functions, such as mobility, adhesion, proliferation, polarization, and differentiation (99). In the normal skin, nectin $1 \alpha$ was colocalized with E-cadherin in cell-cell adherens junctions of the epidermis and was detected in all living layers of the epidermis with the strongest staining in the spinous layer (100). A study on the expression of nectin $1 \alpha$ in NMSC revealed a reduction in staining, more pronounced in morpheaphorm $\mathrm{BCC}$ and in SCC than in the solid type BCC, which is rather consistent with the expression of E-cadherin in NMSC. These results might potentially indicate that reduction of nectin expression could be associated with invasiveness of the tumor, but definitely require further investigation (100).

EpCAM (epithelial cell adhesion molecule) is considered a molecule involved in cellular signaling rather than a cell adhesion molecule, because structurally it does not resemble any of the five major families of CAM, and its classification as an adhesion molecule is still debatable. However, evidence derived from studies on various malignancies indicates that it might be also involved in the development of those pathologies (101).

Physiologically, EpCAM is expressed mainly in glandular epithelial cells, while in pathological conditions, it is mostly overexpressed on the cells of epithelial tumours, but not in non-epithelial tumors (101). There have been reports demonstrating positive staining for EpCAM across all types of BCC (102-105), while loss of its expression was identified in the front of the tumour and in its infiltrative islands (106). There was a negative expression of EpCAM in SCC, irrespective of the histological type or grade of differentiation $(104,105)$. Hence, although in non-cutaneous epithelial malignancies, increased expression of EpCAM has been considered as a predictor of worse clinical outcomes $(107,108)$, the evidence derived from studies on NMSCs appears to be insufficient to confirm such hypotheses.

\section{Conclusion}

Progression of cancer is a result of altered intercellular interactions and loss of adhesion between the neoplastic cells and the extracellular microenvironment. Numerous studies indicate that differences in the expression of adhesion molecules are related to the invasiveness of skin cancers. Downregulation of some, physiologically present, adhesion molecules has been recently suggested to be a sign of a higher tumor metastatic potential. While in the early stages, both SCC and BCC are treatable, in some cases especially SCC recurs locally and even metastasizes leading to death. Therefore, it is important to identify the more aggressive tumors that require closer follow-up. Besides established prognostic factors like size, anatomic site, clinical and histological type of a primary tumor, adhesion molecules 
may become additional prognostic biomarkers of nonmelanoma skin cancers. Cell adhesion molecules could be also an attractive therapeutic target because their extracellular domains could be easily accessed by antibodies or small-molecule inhibitors. Therefore, future research can open new perspectives for more effective skin cancer treatment.

\section{Conflicts of Interest}

The Authors declare that there are no conflicts of interest regarding the publication of this article.

\section{Authors' Contributions}

JCS and JPD contributed to study design, collection of data, writing of the manuscript's draft and the preparation of the final version of the article.

\section{References}

1 Apalla Z, Lallas A, Sotiriou E, Lazaridou E and Ioannides D: Epidemiological trends in skin cancer. Dermatol Pract Concept 7(2): 1-6, 2017. PMID: 28515985. DOI: 10.5826/dpc.0702a01

2 Lesiak A, Czuwara J, Kamińska-winciorek G, Kiprian D, Maj J, Owczarek W, Placek W, Rudnicka L, Rutkowski P, Sobjanek M, Sokołowska-wojdyło M, Szepietowski J, Zegarska B and Zegarski W: Basal cell carcinoma. Diagnostic and therapeutic recommendations of Polish dermatological society. Dermatology Review 106(2): 107-126, 2019. DOI: 10.5114/dr.2019.85572

3 Apalla Z, Nashan D, Weller RB and Castellsagué X: Skin cancer: Epidemiology, disease burden, pathophysiology, diagnosis, and therapeutic approaches. Dermatol Ther (Heidelb) 7(Suppl 1): 5-19, 2017. PMID: 28150105. DOI: 10.1007/s13555-016-0165-y

4 Leiter U, Eigentler T and Garbe C: Epidemiology of skin cancer. Adv Exp Med Biol 810: 120-140, 2014. PMID: 25207363. DOI: 10.1007/978-1-4939-0437-2_7

5 Didona D, Paolino G, Bottoni U and Cantisani C: Non melanoma skin cancer pathogenesis overview. Biomedicines 6(1):6, 2018. PMID: 29301290. DOI: 10.3390/biomedicines 6010006

6 Crowson AN, Magro CM andMihm MC: Squamous cell carcinoma and its precursors. In: Biopsy interpretation of the skin: Primary non-lymphoid cutaneous neoplasia. AN Crowson, CMMagro, MC Mihm Jr (eds.). Philadelphia, Lippincott Williams Wilkins, pp. 288-339, 2010.

7 Janiszewska M, Primi MC and Izard T: Cell adhesion in cancer: Beyond the migration of single cells. J Biol Chem 295(8): 2495-2505, 2020. PMID: 31937589. DOI: 10.1074/ jbc.REV119.007759

8 Cavallaro U and Christofori G: Cell adhesion and signalling by cadherins and Ig-CAMs in cancer. Nat Rev Cancer 4(2): 118132, 2004. PMID: 14964308 . DOI: $10.1038 /$ nrc1276

9 Buechner S, Erne P and Resink T: T-cadherin expression in the epidermis and adnexal structures of normal skin. Dermatopathology 3(4): 68-78, 2020. DOI: 10.1159/000451024
10 Van den Bossche J and Van Ginderachter JA: E-cadherin: From epithelial glue to immunological regulator. Eur J Immunol 43(1): 34-37, 2013. PMID: 23229729. DOI: 10.1002/eji.201243168

11 Brand A, Diener N, Zahner SP, Tripp C, Backer RA, Karram K, Jiang A, Mellman I, Stoitzner P and Clausen BE: E-cadherin is dispensable to maintain langerhans cells in the epidermis. $\mathrm{J}$ Invest Dermatol 140(1): 132-142.e3, 2020. PMID: 31260672. DOI: $10.1016 /$ j.jid.2019.06.132

12 Furukawa F, Fujii K, Horiguchi Y, Matsuyoshi N, Fujita M, Toda $\mathrm{K}$, Imamura S, Wakita H, Shirahama S and Takigawa M: Roles of E- and P-cadherin in the human skin. Microsc Res Tech 38(4): 343-352, 1997. PMID: 9297684. DOI: 10.1002/(SICI)10970029(19970815)38:4<343::AID-JEMT2>3.0.CO;2-K

13 Behrens J, von Kries JP, Kühl M, Bruhn L, Wedlich D, Grosschedl R and Birchmeier W: Functional interaction of betacatenin with the transcription factor LEF-1. Nature 382(6592): 638-642, 1996. PMID: 8757136. DOI: 10.1038/382638a0

14 Bozdogan O, Vargel I, Cavusoglu T, Karabulut A, Karahan G, Sayar N, Atasoy P and Yulug I: Metastasis suppressor proteins in cutaneous squamous cell carcinoma. Pathology - Research and Practice 212(7): 608-615, 2019. DOI: 10.1016/j.prp. 2015.12.018

15 Hodorogea A, Calinescu A, Antohe M, Balaban M, Nedelcu R, Turcu G, Ion D, Badarau I, Popescu C, Popescu R, Popp C, Cioplea M, Nichita L, Hulea I and Brinzea A: Epithelialmesenchymal transition in skin cancers: A review. Analytical Cellular Pathology 2019: 1-11, 2019. DOI: 10.1155/2019/ 3851576

16 Pizarro A, Benito N, Navarro P, Palacios J, Cano A, Quintanilla $\mathrm{M}$, Contreras $\mathrm{F}$ and Gamallo C: E-cadherin expression in basal cell carcinoma. Br J Cancer 69(1): 157-162, 1994. PMID: 8286199. DOI: $10.1038 /$ bjc. 1994.26

17 Tucci M, Lucarini G, Zizzi A, Rocchetti R, Brancorsini D, Primio R, Ricotti F and Ricotti G: Cdc42 is involved in basal cell carcinoma carcinogenesis. Archives of Dermatological Research 305(9): 835-840, 2019. DOI: 10.1007/s00403-0131351-8

18 Fuller LC, Allen MH, Montesu M, Barker JN and Macdonald DM: Expression of E-cadherin in human epidermal nonmelanoma cutaneous tumours. Br J Dermatol 134(1): 28-32, 1996. PMID: 8745882.

19 Majima Y, Hirakawa S, Kito Y, Suzuki H, Koide M, Fukamizu $\mathrm{H}$ and Tokura Y: Twist1 as a possible biomarker for metastatic basal cell carcinoma. Acta Dermato Venereologica 92(6): 621622, 2013. DOI: $10.2340 / 00015555-1422$

20 Vanjaka-Rogošić L, Puizina-Ivić N, Mirić L, Rogošić V, Kuzmić-Prusac I, Babić MS, Vuković D and Mardešić S: Matrix metalloproteinases and E-cadherin immunoreactivity in different basal cell carcinoma histological types. Acta Histochem 116(5): 688-693, 2014. PMID: 24485332. DOI: 10.1016/j.acthis.2013.12.007

21 Papanikolaou S, Bravou V, Gyftopoulos K, Nakas D, Repanti $M$ and Papadaki H: ILK expression in human basal cell carcinoma correlates with epithelial-mesenchymal transition markers and tumour invasion. Histopathology 56(6): 799-809, 2010. PMID: 20546345. DOI: 10.1111/j.1365-2559.2010. 03556.x

22 Nawrocki B, Polette M, Van Hengel J, Tournier JM, Van Roy F and Birembault P: Cytoplasmic redistribution of E-cadherin- 
catenin adhesion complex is associated with down-regulated tyrosine phosphorylation of E-cadherin in human bronchopulmonary carcinomas. Am J Pathol 153(5): 1521-1530, 1998. PMID: 9811344. DOI: 10.1016/s0002-9440(10)65740-9

23 Toll A, Masferrer E, Hernández-Ruiz ME, Ferrandiz-Pulido C, Yébenes M, Jaka A, Tuneu A, Jucglà A, Gimeno J, Baró T, Casado B, Gandarillas A, Costa I, Mojal S, Peña R, de Herreros AG, García-Patos V, Pujol RM and Hernández-Muñoz I: Epithelial to mesenchymal transition markers are associated with an increased metastatic risk in primary cutaneous squamous cell carcinomas but are attenuated in lymph node metastases. J Dermatol Sci 72(2): 93-102, 2013. PMID: 23928229. DOI: 10.1016/j.jdermsci.2013.07.001

24 Tada H, Hatoko M, Muramatsu T and Shirai T: Expression of E-cadherin in skin carcinomas. J Dermatol 23(2): 104-110, 1996. PMID: 8839237. DOI: 10.1111/j.1346-8138.1996. tb03979.x

25 Koseki S, Ansai S, Aoki T, Hozumi Y, Mitsuhashi Y and Kondo $\mathrm{S}$ : E-cadherin expression in skin tumors using an AMeX immunohistostaining method. J Dermatol 27(5): 307-311, 2000. PMID: 10875196. DOI: 10.1111/j.1346-8138.2000.tb02172.x

26 Bălăşoiu AT, Mănescu MR, Bălăşoiu M, Avrămoiu I, Pirici I, Burcea M, Mogoantă L and Mocanu CL: Histological and immunohistochemical study of the eyelid basal cell carcinomas. Rom J Morphol Embryol 56(2 Suppl): 803-810, 2015. PMID: 26429176.

27 Lyakhovitsky A, Barzilai A, Fogel M, Trau H and Huszar M: Expression of e-cadherin and beta-catenin in cutaneous squamous cell carcinoma and its precursors. Am J Dermatopathol 26(5): 372-378, 2004. PMID: 15365368. DOI: 10.1097/00000372-200410000-00005

28 Chen H, Takahara M, Xie L, Takeuchi S, Tu Y, Nakahara T, Uchi H, Moroi Y and Furue M: Levels of the EMT-related protein Snail/Slug are not correlated with p53/p63 in cutaneous squamous cell carcinoma. J Cutan Pathol 40(7): 651-656, 2013. PMID: 23521708. DOI: 10.1111/cup.12142

29 Hesse K, Satzger I, Schacht V, Köther B, Hillen U, Klode J, Schaper K and Gutzmer R: Characterisation of prognosis and invasion of cutaneous squamous cell carcinoma by podoplanin and E-cadherin expression. Dermatology 232(5): 558-565, 2016. PMID: 27875814. DOI: 10.1159/000450920

30 Saenz-Sardà X, Carrato C, Pérez-Roca L, Puig L, Ferrándiz C, Ariza $\mathrm{A}$ and Fernández-Figueras MT: Epithelial-tomesenchymal transition contributes to invasion in squamous cell carcinomas originated from actinic keratosis through the differentiated pathway, whereas proliferation plays a more significant role in the classical pathway. J Eur Acad Dermatol Venereol 32(4): 581-586, 2018. PMID: 28796927. DOI: $10.1111 / j d v .14514$

31 Barrette K, Van Kelst S, Wouters J, Marasigan V, Fieuws S, Agostinis P, van den Oord $\mathrm{J}$ and Garmyn M: Epithelialmesenchymal transition during invasion of cutaneous squamous cell carcinoma is paralleled by AKT activation. Br J Dermatol 171(5): 1014-1021, 2014. PMID: 24628329. DOI: 10.1111/ bjd.12967

32 Lan YJ, Chen H, Chen JQ, Lei QH, Zheng M and Shao ZR: Immunolocalization of vimentin, keratin 17, Ki-67, involucrin, $\beta$-catenin and E-cadherin in cutaneous squamous cell carcinoma. Pathol Oncol Res 20(2): 263-266, 2014. PMID: 23999979. DOI: $10.1007 / \mathrm{s} 12253-013-9690-5$
33 Keiper T, Al-Fakhri N, Chavakis E, Athanasopoulos AN, Isermann B, Herzog S, Saffrich R, Hersemeyer K, Bohle RM, Haendeler J, Preissner KT, Santoso S and Chavakis T: The role of junctional adhesion molecule-C (JAM-C) in oxidized LDL-mediated leukocyte recruitment. FASEB J 19(14): 2078-2080, 2005. PMID: 16195363. DOI: 10.1096/ fj.05-4196fje

34 Majima Y, Hirakawa S, Kito Y, Suzuki H, Koide M, Fukamizu $\mathrm{H}$ and Tokura Y: Twist1 as a possible biomarker for metastatic basal cell carcinoma. Acta Dermato Venereologica 92(6): 621622, 2013. DOI: $10.2340 / 00015555-1422$

35 Islam S, Carey TE, Wolf GT, Wheelock MJ and Johnson KR: Expression of $\mathrm{N}$-cadherin by human squamous carcinoma cells induces a scattered fibroblastic phenotype with disrupted cellcell adhesion. J Cell Biol 135(6 Pt 1): 1643-1654, 1996. PMID: 8978829. DOI: $10.1083 /$ jcb.135.6.1643

36 Shirahama S, Furukawa F, Wakita $\mathrm{H}$ and Takigawa M: E- and $\mathrm{P}$-cadherin expression in tumor tissues and soluble E-cadherin levels in sera of patients with skin cancer. J Dermatol Sci 13(1): 30-36, 1996. PMID: 8902651. DOI: 10.1016/0923-1811(95) 00493-9

37 Vieira AF and Paredes J: P-cadherin and the journey to cancer metastasis. Mol Cancer 14: 178, 2015. PMID: 26438065. DOI: 10.1186/s 12943-015-0448-4

38 Pizarro A, Gamallo C, Benito N, Palacios J, Quintanilla M, Cano A and Contreras F: Differential patterns of placental and epithelial cadherin expression in basal cell carcinoma and in the epidermis overlying tumours. British Journal of Cancer 72(2): 327-332, 2019. DOI: 10.1038/bjc.1995.333

39 Gornowicz-Porowska J, Bowszyc-Dmochowska M, SeraszekJaros A, Kaczmarek E and Dmochowski M: Loss of correlation between intensities of desmoglein 2 and desmoglein 3 expression in basal cell carcinomas. Acta Dermatovenerol Croat 19(3): 150-155, 2011. PMID: 21933638.

40 Tada H, Hatoko M, Tanaka A, Kuwahara M and Muramatsu T: Expression of desmoglein I and plakoglobin in skin carcinomas. J Cutan Pathol 27(1): 24-29, 2000. PMID: 10660128. DOI: 10.1034/j.1600-0560.2000.027001024.x

41 Brennan D and Mahoney MG: Increased expression of Dsg2 in malignant skin carcinomas: A tissue-microarray based study. Cell Adh Migr 3(2): 148-154, 2009. PMID: 19458482. DOI: 10.4161/cam.3.2.7539

42 Pietkiewicz P, Gornowicz-Porowska J, Bowszyc-Dmochowska M, Jagielska J, Helak-Łapaj C, Kaczmarek E and Dmochowski M: Discordant expression of desmoglein 2 and 3 at the mRNA and protein levels in nodular and superficial basal cell carcinoma revealed by immunohistochemistry and fluorescent in situ hybridization. Clin Exp Dermatol 39(5): 628-635, 2014. PMID: 24934917. DOI: 10.1111/ced.12355

43 Kurzen H, Münzing I and Hartschuh W: Expression of desmosomal proteins in squamous cell carcinomas of the skin. J Cutan Pathol 30(10): 621-630, 2003. PMID: 14744087. DOI: 10.1034/j.1600-0560.2003.00122.x

44 Takeuchi T, Liang SB and Ohtsuki Y: Downregulation of expression of a novel cadherin molecule, T-cadherin, in basal cell carcinoma of the skin. Mol Carcinog 35(4): 173-179, 2002. PMID: 12489108 . DOI: $10.1002 / \mathrm{mc} .10088$

45 Takeuchi T, Liang SB, Matsuyoshi N, Zhou S, Miyachi Y, Sonobe $\mathrm{H}$ and Ohtsuki Y: Loss of T-cadherin (CDH13, Hcadherin) expression in cutaneous squamous cell carcinoma. 
Lab Invest 82(8): 1023-1029, 2002. PMID: 12177241. DOI: 10.1097/01.lab.0000025391.35798.f1

46 Mukoyama Y, Utani A, Matsui S, Zhou S, Miyachi Y and Matsuyoshi N: T-cadherin enhances cell-matrix adhesiveness by regulating beta 1 integrin trafficking in cutaneous squamous carcinoma cells. Genes Cells 12(6): 787-796, 2007. PMID: 17573778. DOI: 10.1111/j.1365-2443.2007.01092.x

47 Buechner SA, Philippova M, Erne P, Mathys T and Resink TJ: High T-cadherin expression is a feature of basal cell carcinoma. Br J Dermatol 161(1): 199-202, 2009. PMID: 19438454. DOI: 10.1111/j.1365-2133.2009.09195.x

48 Kyriakakis E, Maslova K, Frachet A, Ferri N, Contini A, Pfaff D, Erne P, Resink TJ and Philippova M: Cross-talk between EGFR and T-cadherin: EGFR activation promotes T-cadherin localization to intercellular contacts. Cell Signal 25(5): 1044-1053, 2013. PMID: 23411345. DOI: 10.1016/j.cellsig.2013.02.001

49 Harjunpää H, Llort Asens M, Guenther C and Fagerholm SC: Cell adhesion molecules and their roles and regulation in the immune and tumor microenvironment. Front Immunol 10: 1078, 2019. PMID: 31231358 . DOI: 10.3389/fimmu.2019.01078

50 Reglero-Real N, Colom B, Bodkin JV and Nourshargh S: Endothelial cell junctional adhesion molecules: Role and regulation of expression in inflammation. Arterioscler Thromb Vasc Biol 36(10): 2048-2057, 2016. PMID: 27515379. DOI: 10.1161/ATVBAHA.116.307610

51 Janes SM and Watt FM: New roles for integrins in squamouscell carcinoma. Nat Rev Cancer 6(3): 175-183, 2006. PMID: 16498442. DOI: $10.1038 / \mathrm{nrc} 1817$

52 Peltonen J, Larjava H, Jaakkola S, Gralnick H, Akiyama SK, Yamada SS, Yamada KM and Uitto J: Localization of integrin receptors for fibronectin, collagen, and laminin in human skin. Variable expression in basal and squamous cell carcinomas. J Clin Invest 84(6): 1916-1923, 1989. PMID: 2556449. DOI: 10.1172/JCI114379

53 Kalluri $\mathrm{R}$ and Weinberg RA: The basics of epithelialmesenchymal transition. J Clin Invest 119(6): 1420-1428, 2009. PMID: 19487818. DOI: 10.1172/JCI39104

54 Wheelock MJ, Shintani Y, Maeda M, Fukumoto Y and Johnson KR: Cadherin switching. J Cell Sci 121(Pt 6): 727-735, 2008. PMID: 18322269 . DOI: $10.1242 /$ jcs.000455

55 Stamp GW and Pignatelli M: Distribution of beta 1, alpha 1, alpha 2 and alpha 3 integrin chains in basal cell carcinomas. J Pathol 163(4): 307-313, 1991. PMID: 2033490. DOI: 10.1002/path.1711630407

56 Orimoto AM, Neto CF, Pimentel ER, Sanches JA, Sotto MN, Akaishi E and Ruiz IR: High numbers of human skin cancers express MMP2 and several integrin genes. J Cutan Pathol 35(3): 285-291, 2008. PMID: 18251742. DOI: 10.1111/j.16000560.2007.00810.x

57 Baum HP, Schmid T and Reichrath J: Integrin molecules: A clue to the non-metastasizing behaviour of basal cell carcinomas? Acta Derm Venereol 76(1): 24-27, 1996. PMID: 8721485. DOI: $10.2340 / 00015555762427$

58 Tuominen H, Junttila T, Karvonen J and Kallioinen M: Celltype related and spatial variation in the expression of integrins in cutaneous tumors. J Cutan Pathol 21(6): 500-506, 1994. PMID: 7699116. DOI: 10.1111/j.1600-0560.1994.tb00719.x

59 Ley K: The role of selectins in inflammation and disease. Trends Mol Med 9(6): 263-268, 2003. PMID: 12829015. DOI: 10.1016/s1471-4914(03)00071-6
60 Keelan ET, Licence ST, Peters AM, Binns RM and Haskard DO: Characterization of E-selectin expression in vivo with use of a radiolabeled monoclonal antibody. Am J Physiol 266(1 Pt 2): H278-H290, 1994. PMID: 7508207. DOI: 10.1152/ajpheart.1994.266.1.H279

61 Pentel M, Helm KF and Maloney MM: Cell surface molecules in basal cell carcinomas. Dermatol Surg 21(10): 858-861, 1995. PMID: 7551741. DOI: 10.1111/j.1524-4725.1995.tb00712.x

62 Groves RW, Allen MH, Ross EL, Ahsan G, Barker JN and MacDonald DM: Expression of selectin ligands by cutaneous squamous cell carcinoma. Am J Pathol 143(4): 1220-1225, 1993. PMID: 7692735.

63 Allen MH, Robinson MK, Stephens PE, MacDonald DM and Barker JN: E-selectin binds to squamous cell carcinoma and keratinocyte cell lines. J Invest Dermatol 106(4): 611-615, 1996. PMID: 8617993. DOI: 10.1111/1523-1747.ep12345385

64 Yasaka N, Furue M and Tamaki K: CD44 expression in normal human skin and skin tumors. J Dermatol 22(2): 88-94, 1995. PMID: 7536764. DOI: 10.1111/j.1346-8138.1995.tb03349.x

65 Marinescu A, Stepan AE, Margaritescu C, Marinescu AM, Zavoi RE and Simionescu CE: CD44 immunoexpression in the progression of actinic keratosis and cutaneous squamous carcinoma. Curr Health Sci J 43(3): 241-245, 2017. PMID: 30595883. DOI: $10.12865 /$ CHSJ.43.03.10

66 Hartmann-Petersen S, Tammi RH, Tammi MI and Kosma VM: Depletion of cell surface CD44 in nonmelanoma skin tumours is associated with increased expression of matrix metalloproteinase 7. Br J Dermatol 160(6): 1251-1257, 2009. PMID: 19222463. DOI: 10.1111/j.1365-2133.2009.09031.x

67 Simon JC, Heider KH, Dietrich A, Wuttig C, Schöpf E, Adolf GR, Ponta $\mathrm{H}$ and Herrlich P: Expression of CD44 isoforms in human skin cancer. Eur J Cancer 32A(8): 1394-1400, 1996. PMID: 8869105. DOI: 10.1016/0959-8049(96)00196-7

68 Grimme HU, Termeer CC, Bennett KL, Weiss JM, Schöpf E, Aruffo A and Simon JC: Colocalization of basic fibroblast growth factor and CD44 isoforms containing the variably spliced exon v3 $(\mathrm{CD} 44 \mathrm{v} 3)$ in normal skin and in epidermal skin cancers. Br J Dermatol 141(5): 824-832, 1999. PMID: 10583162. DOI: 10.1046/j.1365-2133.1999.03154.x

69 Karvinen S, Kosma VM, Tammi MI and Tammi R: Hyaluronan, CD44 and versican in epidermal keratinocyte tumours. Br J Dermatol 148(1): 86-94, 2003. PMID: 12534600. DOI: 10.1046/j.1365-2133.2003.05028.x

70 Kooy AJ, Tank B, de Jong AA, Vuzevski VD, van der Kwast TH and van Joost T: Expression of E-cadherin, alpha- \& betacatenin, and CD44V6 and the subcellular localization of Ecadherin and CD44V6 in normal epidermis and basal cell carcinoma. Hum Pathol 30(11): 1328-1335, 1999. PMID: 10571513. DOI: 10.1016/s0046-8177(99)90064-3

71 Seelentag WK, Günthert U, Saremaslani P, Futo E, Pfaltz M, Heitz PU and Roth J: CD44 standard and variant isoform expression in human epidermal skin tumors is not correlated with tumor aggressiveness but down-regulated during proliferation and tumor de-differentiation. Int J Cancer 69(3): 218-224, 1996. PMID: 8682591. DOI: 10.1002/(SICI)10970215(19960621)69:3<218::AID-IJC12>3.0.CO;2-3

72 Son KD, Kim TJ, Lee YS, Park GS, Han KT, Lim JS and Kang CS: Comparative analysis of immunohistochemical markers with invasiveness and histologic differentiation in squamous cell carcinoma and basal cell carcinoma of the skin. J Surg 
Oncol 97(7): 615-620, 2008. PMID: 18404670. DOI: 10.1002/ jso. 21006

73 Erfani E, Roudi R, Rakhshan A, Sabet MN, Shariftabrizi A and Madjd Z: Comparative expression analysis of putative cancer stem cell markers CD44 and ALDH1A1 in various skin cancer subtypes. Int J Biol Markers 31(1): e53-e61, 2016. PMID: 26391478. DOI: $10.5301 /$ jbm.5000165

74 Sato Y, Mukai K, Matsuno Y, Furuya S, Kagami Y, Miwa M and Shimosato Y: The AMeX method: A multipurpose tissueprocessing and paraffin-embedding method. II. Extraction of spooled DNA and its application to Southern blot hybridization analysis. Am J Pathol 136(2): 267-271, 1990. PMID: 2407122.

75 Wai Wong C, Dye DE and Coombe DR: The role of immunoglobulin superfamily cell adhesion molecules in cancer metastasis. Int J Cell Biol 2012: 340296, 2012. PMID: 22272201. DOI: $10.1155 / 2012 / 340296$

76 Barreiro O, Yanez-Mo M, Serrador JM, Montoya MC, VicenteManzanares M, Tejedor R, Furthmayr H and Sanchez-Madrid F: Dynamic interaction of VCAM-1 and ICAM-1 with moesin and ezrin in a novel endothelial docking structure for adherent leukocytes. J Cell Biol 157(7): 1233-1245, 2002. PMID: 12082081. DOI: $10.1083 /$ jcb.200112126

77 Bevilacqua MP, Nelson RM, Mannori G and Cecconi O: Endothelial-leukocyte adhesion molecules in human disease. Annu Rev Med 45: 361-378, 1994. PMID: 7515220. DOI: 10.1146/annurev.med.45.1.361

78 Dustin ML and Springer TA: Lymphocyte function-associated antigen-1 (LFA-1) interaction with intercellular adhesion molecule-1 (ICAM-1) is one of at least three mechanisms for lymphocyte adhesion to cultured endothelial cells. J Cell Biol 107(1): 321-331, 1988. PMID: 3134364. DOI: $10.1083 / \mathrm{jcb}$. 107.1.321

79 Melendez ND, Smoller BR and Morgan M: VCAM (CD-106) and ICAM (CD-54) adhesion molecules distinguish keratoacanthomas from cutaneous squamous cell carcinomas. Mod Pathol 16(1): 8-13, 2003. PMID: 12527707. DOI: 10.1097/01.MP.0000043520.74056.CD

80 Kikuchi A, Sakuraoka K, Shimizu H and Nishikawa T: Immunohistochemical evaluation of epidermis overlying basal cell carcinomas. Br J Dermatol 128(6): 644-649, 1993. PMID: 7687854. DOI: 10.1111/j.1365-2133.1993.tb00260.x

81 Konter U, Kellner I, Klein E, Kaufmann R, Mielke V and Sterry W: Adhesion molecule mapping in normal human skin. Arch Dermatol Res 281(7): 454-462, 1989. PMID: 2692519. DOI: $10.1007 / \mathrm{BF} 00510080$

82 Taylor RS, Griffiths CE, Brown MD, Swanson NA and Nickoloff BJ: Constitutive absence and interferon-gammainduced expression of adhesion molecules in basal cell carcinoma. J Am Acad Dermatol 22(5 Pt 1): 721-726, 1990. PMID: 1693385. DOI: 10.1016/0190-9622(90)70097-2

83 Kooy AJ, Prens EP, Van Heukelum A, Vuzevski VD, Van Joost $\mathrm{T}$ and Tank B: Interferon-gamma-induced ICAM-1 and CD40 expression, complete lack of HLA-DR and CD80 (B7.1), and inconsistent HLA-ABC expression in basal cell carcinoma: a possible role for interleukin-10?. J Pathol 187(3): 351-357, 1999. PMID: 10398091. DOI: 10.1002/(SICI)10969896(199902)187:3<351::AID-PATH227>3.0.CO;2-6

84 Chaturvedi V, Bonish B, Bacon P, Qin JZ, Denning MF, Foreman K, Diaz MO, Robinson J and Nickoloff BJ: Role for Id-1 in immunobiology of normal keratinocytes and in basal cell carcinoma. Exp Dermatol 12(3): 255-260, 2003. PMID: 12823438. DOI: 10.1034/j.1600-0625.2003.00066.x

85 Chuong CM, Widelitz RB and Jiang TX: Adhesion molecules and homeoproteins in the phenotypic determination of skin appendages. J Invest Dermatol 101(1 Suppl): 10S-15S, 1993. PMID: 8100848. DOI: 10.1111/1523-1747.ep12362447

86 Beljaards RC, Kirtschig G and Boorsma DM: Expression of neural cell adhesion molecule (CD56) in basal and squamous cell carcinoma. Dermatol Surg 34(11): 1577-1579, 2008. PMID: 18798745. DOI: $10.1111 / \mathrm{j} .1524-4725.2008 .34327 . \mathrm{x}$

87 Ishida M, Kushima R and Okabe H: Aberrant expression of class III beta-tubulin in basal cell carcinoma of the skin. Oncol Rep 22(4): 733-737, 2009. PMID: 19724850. DOI: 10.3892/ or_00000494

88 Chen-Tsai CP, Colome-Grimmer $\mathrm{M}$ and Wagner RF Jr: Correlations among neural cell adhesion molecule, nerve growth factor, and its receptors, TrkA, TrkB, TrkC, and p75, in perineural invasion by basal cell and cutaneous squamous cell carcinomas. Dermatol Surg 30(7): 1009-1016, 2004. PMID: 15209791. DOI: $10.1111 / \mathrm{j} .1524-4725.2004 .30306 . \mathrm{x}$

89 Terada T: Expression of NCAM (CD56), chromogranin A, synaptophysin, c-KIT (CD117) and PDGFRA in normal nonneoplastic skin and basal cell carcinoma: An immunohistochemical study of 66 consecutive cases. Med Oncol 30(1): 444, 2013. PMID: 23292839. DOI: 10.1007/s12032-012-0444-0

90 Peterson SC, Eberl M, Vagnozzi AN, Belkadi A, Veniaminova NA, Verhaegen ME, Bichakjian CK, Ward NL, Dlugosz AA and Wong SY: Basal cell carcinoma preferentially arises from stem cells within hair follicle and mechanosensory niches. Cell Stem Cell 16(4): 400-412, 2015. PMID: 25842978. DOI: 10.1016/ j.stem.2015.02.006

91 Wang GY, Wang J, Mancianti ML and Epstein EH Jr: Basal cell carcinomas arise from hair follicle stem cells in Ptch1(+/-) mice. Cancer Cell 19(1): 114-124, 2011. PMID: 21215705. DOI: $10.1016 /$ j.ccr.2010.11.007

92 Youssef KK, Van Keymeulen A, Lapouge G, Beck B, Michaux C, Achouri Y, Sotiropoulou PA and Blanpain C: Identification of the cell lineage at the origin of basal cell carcinoma. Nat Cell Biol 12(3): 299-305, 2010. PMID: 20154679. DOI: 10.1038/ncb2031

93 Wong SY and Reiter JF: Wounding mobilizes hair follicle stem cells to form tumors. Proc Natl Acad Sci USA 108(10): 40934098, 2011. PMID: 21321207. DOI: 10.1073/pnas.1013098108

94 DeLisser HM, Christofidou-Solomidou M, Strieter RM, Burdick MD, Robinson CS, Wexler RS, Kerr JS, Garlanda C, Merwin JR, Madri JA and Albelda SM: Involvement of endothelial PECAM-1/CD31 in angiogenesis. Am J Pathol 151(3): 671-677, 1997. PMID: 9284815.

95 Lertkiatmongkol P, Liao D, Mei H, Hu Y and Newman PJ: Endothelial functions of platelet/endothelial cell adhesion molecule-1 (CD31). Curr Opin Hematol 23(3): 253-259, 2016. PMID: 27055047. DOI: 10.1097/MOH.0000000000000239

96 Chin CW, Foss AJ, Stevens A and Lowe J: Differences in the vascular patterns of basal and squamous cell skin carcinomas explain their differences in clinical behaviour. J Pathol 200(3): 308-313, 2003. PMID: 12845626. DOI: 10.1002/path.1363

97 Ciortea CD, Jung I, Gurzu S, Kövecsi A, Turdean SG and Bara $\mathrm{T}$ : Correlation of angiogenesis with other immunohistochemical markers in cutaneous basal and squamous cell carcinomas. Rom J Morphol Embryol 56(2 Suppl): 665-670, 2015. PMID: 26429157. 
98 Krediet JT, Kanitakis J, Bob A, Schmitter J, Krediet AC, Röwert J, Stockfleth E, Painsi C, Hügel R, Terhorst D and Lange-Asschenfeldt B: Prognostic value of the area and density of lymphatic vessels in cutaneous squamous cell carcinoma. J Dtsch Dermatol Ges 14(11): 1114-1121, 2016. PMID: 27879093. DOI: $10.1111 /$ ddg.12880

99 Rikitake $\mathrm{Y}$, Mandai $\mathrm{K}$ and Takai Y: The role of nectins in different types of cell-cell adhesion. J Cell Sci 125(Pt 16): 3713-3722, 2012. PMID: 23027581. DOI: 10.1242/jcs.099572

100 Matsushima H, Utani A, Endo H, Matsuura H, Kakuta M, Nakamura Y, Matsuyoshi N, Matsui C, Nakanishi H, Takai Y and Shinkai $\mathrm{H}$ : The expression of nectin-1alpha in normal human skin and various skin tumours. Br J Dermatol 148(4): 755-762, 2003. PMID: 12752135. DOI: 10.1046/j.13652133.2003.05225.x

101 Balzar M, Winter MJ, de Boer CJ and Litvinov SV: The biology of the 17-1A antigen (Ep-CAM). J Mol Med (Berl) 77(10): 699-712, 1999. PMID: 10606205. DOI: 10.1007/ s001099900038

102 Sellheyer K and Krahl D: Basal cell (trichoblastic) carcinoma common expression pattern for epithelial cell adhesion molecule links basal cell carcinoma to early follicular embryogenesis, secondary hair germ, and outer root sheath of the vellus hair follicle: A clue to the adnexal nature of basal cell carcinoma? J Am Acad Dermatol 58(1): 158-167, 2008. PMID: 18158927. DOI: $10.1016 /$ j.jaad.2007.07.008

103 Kist D, Perkins W, Christ S and Zachary CB: Anti-human epithelial antigen (Ber-EP4) helps define basal cell carcinoma masked by inflammation. Dermatol Surg 23(11): 1067-1070, 1997. PMID: 9391566. DOI: 10.1111/j.1524-4725.1997. tb00449.x
104 Dasgeb B, Mohammadi TM and Mehregan DR: Use of BerEP4 and epithelial specific antigen to differentiate clinical simulators of basal cell carcinoma. Biomark Cancer 5: 7-11, 2013. PMID: 24179394. DOI: 10.4137/BIC.S11856

105 Tellechea O, Reis JP, Domingues JC and Baptista AP: Monoclonal antibody Ber EP4 distinguishes basal-cell carcinoma from squamous-cell carcinoma of the skin. Am J Dermatopathol 15(5): 452-455, 1993. PMID: 8238781. DOI: 10.1097/00000372-199310000-00007

106 Gaiser MR, Hirsch D and Gaiser T: Loss of epithelial cell adhesion molecule (EpCAM) in infiltrative basal cell carcinoma. Int J Clin Exp Pathol 11(1): 406-412, 2018. PMID: 31938125

107 Went PT, Lugli A, Meier S, Bundi M, Mirlacher M, Sauter G and Dirnhofer S: Frequent EpCam protein expression in human carcinomas. Hum Pathol 35(1): 122-128, 2004. PMID: 14745734. DOI: $10.1016 /$ j.humpath.2003.08.026

108 Herreros-Pomares A, Aguilar-Gallardo C, Calabuig-Fariñas S, Sirera R, Jantus-Lewintre E and Camps C: EpCAM duality becomes this molecule in a new Dr. Jekyll and Mr. Hyde tale. Crit Rev Oncol Hematol 126: 52-63, 2018. PMID: 29759567. DOI: $10.1016 /$ j.critrevonc.2018.03.006

Received February 12, 2021

Revised March 5, 2021

Accepted March 19, 2021 